\title{
Analisis efisiensi industri perbankan Indonesia setelah merger dan akuisisi: Pendekatan data envelopment analysis
}

\author{
Yoshua Harbyanto Sipangkar* \\ Bursa Efek Indonesia \\ Gedung Bursa Efek Indonesia, Tower 1, Lantai 6 Jl. Jend. Sudirman Kav 52-53 \\ Jakarta Selatan 12190, Indonesia \\ yoshuaharbyanto@gmail.com \\ Estro Dariatno Sihaloho \\ Center for Economics and Development Studies (CEDS) Universitas Padjadjaran \\ Jalan Cimandiri no. 6-8, Bandung 40115, Indonesia \\ estro.sihaloho@unpad.ac.id \\ *Penulis Korespondensi
}

Submitted: Mar 29, 2020; Reviewed: Apr 6, 2020; Accepted: May 8, 2020

\begin{abstract}
This article determines the factor that influences bank efficiency after mergers and acquisitions. The efficiency calculation uses Data Envelopment Analysis (DEA) approach. To test the factors, we use cross-section method in the first three years after mergers and acquisitions. The studies are analyzing the impact of identical factors with bank characteristics such as governance, credit risk, capital adequacy, and loan intensity on bank efficiency, herewith total assets as a control variable. The result shows that governance and credit risk have no significant effect on bank efficiency after mergers and acquisitions. Capital adequacy has a positive and significant effect on bank efficiency in the first three years after mergers and acquisitions. Loan intensity has a positive and significant effect on bank efficiency in the second and third years.
\end{abstract}

Keywords: bank; data envelopment analysis (DEA); efficiency; mergers and acquisitions

Abstrak: Tujuan dari penelitian ini dilakukan untuk mengetahui faktor yang mempengaruhi efisiensi bank setelah merger dan akuisisi. Perhitungan efisiensi menggunakan pendekatan Data Envelopment Analysis (DEA). Pengujian terhadap faktor yang diteliti menggunakan metode cross-section pada tiga tahun pertama setelah merger dan akuisisi. Penelitian ini menganalisis pengaruh dari factor yang identik dengan karakteristik bank seperti tata kelola, risiko kredit, kecukupan modal, dan intensitas pinjaman terhadap efisiensi bank setelah merger dan akuisisi, dengan ukuran bank sebagai variabel kontrol. Hasil pengujian menunjukkan bahwa tata kelola dan risiko kredit tidak berpengaruh secara signifikan terhadap efisiensi bank setelah merger dan akuisisi. Kecukupan modal berpengaruh positif dan signifikan terhadap efisiensi bank pada tiga tahun pertama setelah merger dan akuisisi. Intensitas pinjaman berpengaruh positif dan signifikan terhadap efisiensi bank pada pada tahun 2 dan tahun 3 setelah merger dan akuisisi.

Kata kunci: bank; data envelopment analysis (DEA); efisiensi; merger dan akuisisi 


\section{PENDAHULUAN}

Krisis ekonomi pada tahun 1997 telah mengingatkan kembali pada pentingnya rekstrukturisasi industri perbankan serta pentingnya prudensial perbankan (Mulyaningsih \& Daly, 2012). Industri perbankan menjadi salah satu fokus penting karena menurut Undang-Undang Nomor 10 tahun 1998, bank merupakan lembaga perantara keuangan yang bertugas untuk menghimpun dana dari masyarakat. Peran bank sebagai suatu lembaga perantara keuangan (financial intermediary) menjadikan industri perbankan menjadi sektor yang cukup strategis dalam perekonomian. Upaya Bank Indonesia untuk menguatkan sistem keuangan nasional adalah dengan menerapkan kebijakan konsolidasi pada sektor perbankan. Kebijakan ini dimulai sejak 1997 melalui Pengumuman Pemerintah 1 November 1997 untuk melakukan konsolidasi empat bank pemerintah dan likuidasi 23 bank.

Selanjutnya, proses konsolidasi terus berjalan dan pada tahun 2004 diperkenalkan melalui kebijakan Arsitektur Perbankan Indonesia (API).Terdapat dua kebijakan dalam API yang mendorong terjadinya pertumbuhan merger dan akuisisi, antara lain Peraturan Bank Indonesia Nomor 10/15/PBI/2008 (2008) perihal aturan jumlah modal minimal perbankandan Peraturan Bank Indonesia Nomor 8/16/PBI/2006 (2006) yang mengatur tentang kepemilikan tunggal atau single presence policy(Mulyaningsih \& Daly, 2012).Sementara itu dengan dorongan rencana yang disusun untuk menciptakan sistem perbankan lebih kuat dan efisien, API mengonsolidasikan industri dan menurunkan jumlah bank saat ini menjadi 59 sampai 60 bank dalam 10 tahun ke depan. Melalui kebijakan kebutuhan modal minimum(single presence policy) yang termasuk dalam tujuan berdirinya API, Tabel 1 memaparkan transkasi merger dan akuisisi yang berhasil dilakukan dalam industri perbankan di Indonesia dari tahun 2006 sampai dengan 2014.

Efisiensi adalah salah satu indikator penting untuk menganalisis kinerja bank, karena sistem perbankan yang efisien berkontribusi secara luas untuk pertumbuhan ekonomi yang lebih tinggi di negara manapun (Sufian \& Majid, 2007). Penting untuk melihat dampak setelah merger dan akuisisi bagi bank karena merger dan akuisisi dapat menyebabkan perubahan dalam efisiensi, kekuatan pasar, skala dan cakupan ekonomi, serta ketersediaan layanan kepada nasabah dan efisiensi sistem pembayaran (Berger \& Humphrey 1997).Sejak tahun 1980, banyak bankir dan analis bank menyatakan bahwa merger dan akuisisi dapat menghasilkan efisiensi (Rhoades, 1998).

Namun, efisiensi tidak begitu saja terbentuk setelah dilakukannya merger dan akuisisi. Ada berbagai faktor yang dapat mempengaruhi terjadinya efisiensi bank setelah aktivitas merger dan akuisisi, antara lain faktor internal (karakteristik bank) dan faktor eksternal (industri dan ekonomi makro). Pada penelitian ini, faktor yang diteliti merupakan faktor spesifik terhadap karakteristik bank, karena determinan faktor penentu efisiensi operasional suatu perusahaan secara langsung di antaranya adalah karakteristik perusahaan (Badunenko, Fritsch \& Stephan, 2006), antara lain tata kelola, risiko kredit, kecukupan modal, dan intensitas pinjaman.

BerdasarkanPeraturan Bank Indonesia Nomor 8/4/PBI/2006(2006),sebagaimana diamandemen oleh Peraturan Bank Indonesia Nomor 8/14/2006 (2006)mengenai penerapan Good Corporate Governance (GCG) pada bank umum, peraturan ini menjadi bukti pentingnya GCG dalam dunia perbankan (Permatasari \& Novitasary, 2014). Secara keseluruhan, melalui proksi komposisi komisaris independen terhadap dewan direksi, tata kelola cenderung mempengaruhi kemampuan bank secara positif untuk meningkatkan efisiensi (Tanna et al., 2011). Risiko kredit, dengan proksi dari non performing loan ratio yang tinggi (kredit macet yang tinggi), menandakan bank menanggung biaya yang lebih tinggi dan menjadikan bank menjadi tidak efisien (Niţoi \& Spulbar, 2015). Hal tersebut terjadi karena untuk mengurangi tingkat kredit bermasalah, sehingga bank memerlukan biaya lebih tinggi terkait dengan pemantauan, negosiasi pengaturan, mengambil dan mengatur agunan, serta mengalihkan fokus manajerial senior (Berger \& DeYoung, 1997).

Peraturan Bank Indonesia Nomor 10/15/PBI/2008 (2008)yang diamandemen melalui Peraturan Bank IndonesiaNomor 15/12/PBI/2013 (2013) mewajibkan seluruh bank di Indonesia memenuhi kriteria penyediaan modal minimum, menjadikan kecukupan modal sebagai salah satu kriteria penting dalam mendukung pertumbuhan perbankan di Indonesia. Kecukupan modal, melalui proksi capital adequacy ratio, yang baik memiliki kemungkinan kecil menghadapi biaya kebangkrutan, sehingga dapat mengurangi biaya peminjaman. Intensitas pinjaman (loan intensity), menunjukkan bahwa bank dengan rasio kredit terhadap aset yang tinggi cenderung menunjukkan tingkat efisiensi yang lebih 
tinggi (Sufian \& Noor, 2009). Isik \& Hassan (2003) berpendapat bahwa hubungan antara aktivitas pinjaman dan efisiensi bank dapat dikaitkan dengan kemampuan bank yang relatif efisien untuk mengelola operasi secara lebih produktif, sehingga mempunyai kesempatan untuk menanggung biaya yang lebih rendah.

Tabel 1. Transaksi merger dan akuisisi perbankan di Indonesia periode 2006-2014

\begin{tabular}{|c|c|c|c|}
\hline Tahun & Bank yang Merger atau Aku & & Hasil Merger atau Akuisisi \\
\hline 2014 & Bank Himpunan Saudara & Bank Woori Indonesia & Bank Woori Saudara \\
\hline 2014 & Bank Mutiara & $\mathrm{J}$ Trust & Bank Jtrust Indonesia \\
\hline 2013 & Bank Index Selindo & Creator Capital & Bank Index Selindo \\
\hline 2013 & Bank Tabungan Pensiunan & Sumitomo Mitsui & Bank Tabungan Pensiunan \\
\hline & Nasional (BTPN) & Banking Corporation & Nasional (BTPN) \\
\hline 2011 & Bank Kesawan & Qatar National Bank & Bank QNB Kesawan \\
\hline 2010 & Bank NISP & Bank OCBC Indonesia & Bank OCBC NISP \\
\hline 2010 & Bank Buana & Bank UOB Indonesia & Bank UOB Indonesia \\
\hline 2010 & Bank Dipo Internasional & Sampoerna Strategic & Bank Sahabat Sampoerna \\
\hline 2009 & $\begin{array}{l}\text { Bank Utama International } \\
\text { Bank (UIB) }\end{array}$ & $\begin{array}{l}\text { Bank Central Asia } \\
\text { (BCA) }\end{array}$ & Bank BCA Syariah \\
\hline 2008 & $\begin{array}{l}\text { Bank Haga dan Bank } \\
\text { Hagakita }\end{array}$ & Bank Rabobank Duta & $\begin{array}{l}\text { Bank Rabobank International } \\
\text { Indonesia }\end{array}$ \\
\hline 2008 & Bank Ekonomi Raharja & HSBC & Bank Ekonomi Raharja \\
\hline 2008 & Bank Lippo & Bank Niaga & Bank CIMB Niaga \\
\hline 2007 & Bank Artha Niaga Kencana & Bank Commonwealth & Bank Commonwealth \\
\hline 2007 & Bank Multicor & Bank Windu Kentjana & $\begin{array}{l}\text { Bank Windu Kentjana } \\
\text { International Tbk. }\end{array}$ \\
\hline 2007 & Bank Halim Indonesia & $\begin{array}{l}\text { Industrial and } \\
\text { Commercial Bank of } \\
\text { China (ICBC) }\end{array}$ & Bank ICBC Indonesia \\
\hline 2007 & Bank Sri Partha & $\begin{array}{l}\text { Mercy Corps IFC, } \\
\text { Hivos-Triodos Fund, } \\
\text { and CORDAID }\end{array}$ & Bank Andara \\
\hline 2007 & Bank Swadesi & State Bank of India & Bank Swadesi \\
\hline 2007 & Bank Finconesia & Commerzbank & Bank Agris \\
\hline 2007 & $\begin{array}{l}\text { Bank Nusantara } \\
\text { Parahyangan }\end{array}$ & $\begin{array}{l}\text { Acom Co. Ltd. and } \\
\text { BoTM-UFJ }\end{array}$ & Bank Nusantara Parahyangan \\
\hline 2006 & Bank UFJ Indonesia & $\begin{array}{l}\text { Bank of Tokyo } \\
\text { Mitsubishi UFJ }\end{array}$ & $\begin{array}{l}\text { Bank of Tokyo Mitsubishi } \\
\text { UFJ }\end{array}$ \\
\hline
\end{tabular}

Sumber: Diolah dari Bank Indonesia (2011) dan McGauran (2017)

Penelitian dilakukan pada periode setelah merger dan akusisi karena merger dan akuisisi bisa mengarah ke efisiensi laba yang lebih tinggi dari bank melalui peningkatan efisiensi pendapatan selama periode setelah merger (Sufian, Muhammad, Noordin, \& Kamarudin, 2013). Jangka waktu tiga tahun digunakan karena adanya kesepakatan di antara para ahli bahwa sekitar setengah dari setiap peningkatan efisiensi harus jelas setelah satu tahun dan semua keuntungan harus direalisasikan dalam waktu tiga tahun(Rhoades, 1998). Penelitian ini dilakukan dengan melihat efisiensi bank untuk masing-masing tiga tahun pertama setelah merger dan akuisisi serta meneliti pengaruh terhadap efisiensi di setiap tahun setelah merger dan akusisi terhadap beberapa faktor yang mempengaruhi.

Hipotesis awal dalam penelitian ini dapat diuraikan sebagai berikut.

$\mathrm{H}_{1}$ : Tata kelola berpengaruh positif terhadap efisiensi bank setelah merger dan akuisisi

$\mathrm{H}_{2}$ : Risiko kredit berpengaruh negatif terhadap efisiensi bank setelah merger dan akuisisi 
$\mathrm{H}_{3}$ : Kecukupan modal berpengaruh positif terhadap efisiensi bank setelah merger dan akuisisi $\mathrm{H}_{4}$ : Intensitas pinjaman berpengaruh positif terhadap efisiensi bank setelah merger dan akuisisi

\section{METODE}

Data yang digunakan dalam penelitian ini adalah data sekunder berupa data kinerja keuangan perusahaan. Metode pengambilan sampel yang digunakan dalam penelitian ini adalah metode purposive sampling. Beberapa kriteria yang dijadikan dasar pengambilan sampel antara lain perusahaan merupakan hasil dari transaksi merger dan akuisisi selama periode 2006 hingga 2014, berbasis di Indonesia, tipe bank konvensional, memiliki data laporan keuangan tahunan tiga tahun pertama setelah melakukan merger dan akuisisi, memiliki data laporan keuangan tahunan, serta laporan tahunan yang menyediakan variabel yang digunakan. Dari populasi berjumlah 20 bank, diperoleh sampel sebesar 18 bank.

Perhitungan efisiensi bank setelah merger dan akuisisi menggunakan metode data envelopment analysis (DEA). DEA adalah pendekatan untuk mengukur tingkat efisiensi dengan mengubah beberapa input menjadi beberapa output yang disebut decision making units (DMU). Pendekatan DEA akan mengevaluasi kinerja dan menghasilkan skor efisiensi yang relatif (Charnes et al., 1978). Studi ini menggunakan aplikasi $R$ dalam proses pendekatan DEA.

$\operatorname{Max} \theta$

\section{Subject to:}

$$
\begin{aligned}
& \sum_{j=1}^{n} \lambda_{j} X_{i j} \leq X_{i 0} i=1,2, \ldots, m \\
& \sum_{j=1}^{n} \lambda_{j} Y_{r j} \leq \theta Y_{r 0} r=1,2, \ldots, s \\
& \sum_{j=1}^{n} \lambda_{j}=1 \quad \lambda_{j} \geq 0 j=1,2, \ldots, n
\end{aligned}
$$

Pendekatan DEA menunjukkan bahwa skor efisiensi dengan nilai $0<\theta<1 . \mathrm{X}_{\mathrm{i} 0 \mathrm{dan}} \mathrm{Y}_{\mathrm{r} 0}$ merupakan $i^{\text {th }}$ input dan $r^{\text {th }}$ output untuk DMU dan $\mathrm{j}=1,2 \ldots$ menyatakan jumlah DMU (Charnes et al., 1978). Dalam mengolah data, sampel penelitian ini merupakan bank hasil merger atau akusisi dikategorikan sebagai DMU.DEA melakukan pengukuran skor efisiensi relatif dengan membandingkan beberapa input dan beberapa output untuk setiap DMU. Tabel 2 memaparkan bank yang terpilih sebagai DMU, yang juga merupakan sampel penelitian ini.

Nilai efisiensi sebagai variabel dependen dan dilakukan penelitian untuk mengetahui pengaruh variabel independen terhadap variabel dependen pada tahun 1, tahun 2, dan tahun 3 setelah merger dan akuisisi. Pada penelitian inidilakukan regresi cross-section pada tahun 1, tahun 2 dan tahun 3 setelah merger dan akuisisi.Teknik analisis data dalam penelitian ini menggunakan analisis regresi linier berganda untuk memperoleh gambaran yang menyeluruh mengenai pengaruh antara variabel satu dengan variabel yang lain.

Model regresi linier berganda yang digunakan untuk tahun pertama, kedua, dan ketiga dengan tidak menggunakan variabel kontrol sebagai berikut.

$$
\mathrm{EFF}_{\mathrm{i}}=\beta_{0}+\beta_{1} \mathrm{GCG}_{\mathrm{i}}+\beta_{2} \mathrm{NPL}_{\mathrm{i}}+\beta_{3} \mathrm{CAR}_{\mathrm{i}}+\beta_{4} \mathrm{LOANTA}_{\mathrm{i}}+\mu_{\mathrm{i}}
$$

Model regresi linier berganda yang digunakan untuk tahun pertama, kedua, dan ketiga dengan menggunakan variabel kontrol dapat dirumuskan sebagai berikut.

$$
\mathrm{EFF}_{\mathrm{i}}=\beta_{0}+\beta_{1} \mathrm{GCG}_{\mathrm{i}}+\beta_{2} \mathrm{NPL}_{\mathrm{i}}+\beta_{3} \mathrm{CAR}_{\mathrm{i}}+\beta_{4} \mathrm{LOANTA}_{\mathrm{i}}+\beta_{5} \mathrm{SIZE}_{\mathrm{i}}+\mu_{\mathrm{i}}
$$


Tabel 2. Decision making unit (DMU)

\begin{tabular}{ll}
\hline DMU & Nama bank setelah merger atau akuisisi \\
\hline 1 & Bank Nusantara Parahyangan, Tbk. \\
2 & Bank Agris, Tbk. \\
3 & Bank Swadesi, Tbk. \\
4 & Bank Andara \\
5 & Bank ICBC Indonesia \\
6 & Bank Windu Kentjana International, Tbk. \\
7 & Bank Commonwealth \\
8 & Bank Ekonomi Rahardja, Tbk. \\
9 & Bank Rabobank International Indonesia \\
10 & Bank CIMB Niaga, Tbk. \\
11 & Bank Sahabat Sampoerna \\
12 & Bank OCBC NISP, Tbk. \\
13 & Bank UOB Indonesia \\
14 & Bank QNB Kesawan, Tbk. \\
15 & Bank Tabungan Pensiun Negara, Tbk. \\
16 & Bank Index Selindo \\
17 & Bank Jtrust Indonesia, Tbk. \\
18 & Bank Woori Saudara, Tbk. \\
\hline
\end{tabular}

Sumber: Diolah dari Bank Indonesia (2011) dan McGauran (2017)

\section{HASIL DAN PEMBAHASAN}

Bank dapat dikatakan efisien apabila memiliki skor efisiensi sama dengan 1 (Charneset al., 1978) atau dapat dipersentasekan menjadi 100 persen. Jika nilai skor efisiensi kurang dari satu, maka suatu bank belum dapat dikatakan efisien. Kemudian, dilakukan pengujian untuk menjelaskan secara deskriptif ada tidaknya perbedaan efisiensi setelah merger dan akuisisi pada setiap tahun ke tahun serta sebelum dan sesudah merger dan akuisisi dengan menggunakan uji beda Anova F-test. Pengujian dilakukan dengan ketentuan: jika $p$ value $<\alpha$, maka ada perbedaan dan jika $p$ value $>\alpha$ maka tidak ada perbedaan. Tingkat signifikansi atau $\alpha=5 \%$ dengan notasi $\left({ }^{*}\right)$. Berikut nilai skor efisiensi bank setelah merger dan akuisisi, rata-rata (mean) setiap tahun, dan probabilitas uji beda setelah merger dan akuisisi untuk setiap tahun, serta hasil uji beda efisiensi bank sebelum dan sesudah merger dan akuisisi yang terdapat pada Tabel 3 dan 4 di bawah ini.

Berdasarkan Tabel 3, bank yang efisien pada tahun pertama sebanyak 11 perusahaan; tahun kedua sebanyak 12 perusahaan; dan tahun ketiga sebanyak 10 perusahaan. Dari tiga periode analisis, tahun 2 menghasilkan lebih banyak bank yang efisien dibandingkan tahun 1 dan tahun 3. Kemudian, hasil ratarata yang diperoleh setiap tahun yang terdapat pada Tabel 3, dilihat bahwa rata-rata perolehan skor efisiensi pada tahun 1 sebesar 95,51 persen, tahun 2 sebesar 94,90 persen, dan tahun 3 sebesar 95,79 persen. Maka, skor efisiensi tertinggi diperoleh pada tahun 3 setelah merger dan akuisisi serta dapat dinyatakan bahwa hasil efisiensi yang maksimal mampu diperoleh pada tahun 3 . Hal ini sesuai dengan pendapat para ahli yang diperoleh dari penelitian Rhoades (1998) bahwa seharusnya seluruh keuntungan efisiensi dapat diperoleh pada tahun ketiga.

Bank yang selama tiga tahun tidak mencapai efisiensi (selama tiga tahun tidak mendapatkan skor sebesar satu) sebanyak lima perusahaan, antara lain Bank Nusantara Parahyangan, Tbk., Bank Windu Kentjana International, Tbk., Bank Commonwealth, Bank Sahabat Sampoerna, dan Bank Jtrust Indonesia, Tbk. Tri Santoso (2010)mengungkapkan bahwa bank yang melakukan merger dan akuisisi belum tentu akan menyebabkan efisien jika bank tidak dapat mengendalikan beban-beban biaya bunga dan tenaga kerja di lingkungan internalnya serta membuat aset bank lebih produktif dengan memberikan pinjaman kepada pihak luar yang berkualitas dan mengurangi pemberian kredit kepada pihak terkait bank. 
Tabel 3. Skor efisiensi dan uji beda merger dan akuisisi (M\&A)

\begin{tabular}{llrrr}
\hline Tahun & Nama Bank Setelah M\&A & \multicolumn{3}{c}{ Hasil Setelah M\&A } \\
\cline { 3 - 5 } M\&A & & Tahun 1 & Tahun 2 & \multicolumn{1}{c}{ Tahun 3 } \\
\hline 2007 & Bank Nusantara Parahyangan & $95,81 \%$ & $89,31 \%$ & $94,80 \%$ \\
2007 & Bank Agris, Tbk. & $100 \%$ & $100 \%$ & $100 \%$ \\
2007 & Bank Swadesi, Tbk. & $95 \%$ & $100 \%$ & $100 \%$ \\
2007 & Bank Andara & $100 \%$ & $100 \%$ & $100 \%$ \\
2007 & Bank ICBC Indonesia & $100 \%$ & $100 \%$ & $100 \%$ \\
2007 & Bank Windu Kentjana International, Tbk. & $89,57 \%$ & $84,26 \%$ & $80,34 \%$ \\
2007 & Bank Commonwealth & $80,13 \%$ & $75,72 \%$ & $94,98 \%$ \\
2008 & Bank Ekonomi Rahardja, Tbk. & $100 \%$ & $97,10 \%$ & $100 \%$ \\
2008 & Bank Rabobank International Indonesia, Tbk. & $100 \%$ & $100 \%$ & $91,10 \%$ \\
2008 & Bank CIMB Niaga, Tbk. & $100 \%$ & $100 \%$ & $100 \%$ \\
2010 & Bank Sahabat Sampoerna & $88,64 \%$ & $74,55 \%$ & $81,51 \%$ \\
2010 & Bank OCBC NISP, Tbk. & $100 \%$ & $100 \%$ & $100 \%$ \\
2010 & Bank UOB Indonesia & $100 \%$ & $100 \%$ & $99,59 \%$ \\
2011 & Bank QNB Kesawan, Tbk. & $95,37 \%$ & $100 \%$ & $87,47 \%$ \\
2013 & Bank Tabungan Pensiun Negara, Tbk. & $100 \%$ & $100 \%$ & $100 \%$ \\
2013 & Bank Index Selindo & $100 \%$ & $100 \%$ & $100 \%$ \\
2014 & Bank Jtrust Indonesia, Tbk. & $74,66 \%$ & $87,28 \%$ & $94,51 \%$ \\
2014 & Bank Woori Saudara, Tbk. & $100 \%$ & $100 \%$ & $100 \%$ \\
\hline Rata-Rata & $95,51 \%$ & $94,90 \%$ & $95,79 \%$ \\
\hline Probabilitas $(p$-value) & \multicolumn{3}{c}{0,9383} & \\
\hline Sumber: Data hasil pengolahan & & &
\end{tabular}

Sumber: Data hasil pengolahan

Tabel 4. Perbandingan sebelum dan sesudah merger dan akuisisi

\begin{tabular}{|c|c|c|}
\hline \multirow[b]{2}{*}{ Rata-Rata Skor Efisiensi } & Sebelum M\&A & Sesudah M\&A \\
\hline & $87,29 \%$ & $95,40 \%$ \\
\hline Probabilitas (p-value) & 0,014 & \\
\hline
\end{tabular}

Tabel 4 menunjukkan hasil uji beda yang digunakan untuk melihat dampak dari merger dan akuisisi melalui ada tidaknya perbedaan hasil efisiensi pada setiap tahun dengan cara membandingkan dari tahun per tahun setelah merger dan akuisisi. Hasilnya adalah tidak ada perbedaan yang signifikan pada seluruh perbandingan tiap periode karena angka probabilitas dari uji beda sebesar 0,9383, lebih besar dari tingkat signifikansi sebesar 5 persen. Hal ini berarti efisiensi setelah merger dan akuisisi di setiap tahunnya tidak terjadi perbedaan secara signifikan. Hal tersebut bisa terjadi karena setengah hasil keuntungan efisiensi sudah diperoleh pada tahun pertama dan sisanya didapatkan sampai tahun 3 (Rhoades, 1998), sehingga perbedaan tiap tahun setelah merger dan akuisisi tidak terlalu berubah jauh.

Estimasi persamaan regresi cross-section dibagi pada tiga hasil uji regresi karena dilakukan tiga kali regresi terhadap tiga tahun pertama setelah merger dan akusisi. Hasil regresi yang ditampilkan dibagi menjadi dua panel, yaitu panel A dengan model tidak menggunakan variabel kontrol sedangkan panel B model regresi yang menggunakan variabel kontrol (SIZE). Dari hasil regresi, penelitian ini tidak dapat menolak hipotesis awal dan hal ini juga sesuai dengan penelitian sebelumnya.Hasil perhitungan regresi cross-sectiondijelaskan pada Tabel 5.

Pemilihan SIZE, yang berupa natural logaritma dari total aset, sebagai variabel kontrol sesuai dengan penelitian Isik \& Hassan (2003) dan Tanna et al. (2011) yang menggunakannya dalam model regresi merupakan pilihan yang tepat dalam model, karena keberadaan total aset diasumsikan netral dan mampu mengurangi error dalam model regresi. 
Tabel 5. Rangkuman hasil estimasi data

Panel A: $\mathrm{EFF}_{\mathrm{i}}=\beta_{0}+\beta_{1} \mathrm{GCG}_{\mathrm{i}}+\beta_{2} \mathrm{NPL}_{\mathrm{i}}+\beta_{3} \mathrm{CAR}_{\mathrm{i}}+\beta_{4} \mathrm{LOANTA}_{\mathrm{i}}+\mu_{\mathrm{i}}$

Panel B: EFF $=\beta_{0}+\beta_{1}$ GCG $_{i}+\beta_{2}$ NPL $_{i}+\beta_{3}$ CAR $_{i}+\beta_{4}$ LOANTA $_{i}+\beta_{5}$ SIZE $_{i}+\mu_{i}$

\begin{tabular}{|c|c|c|c|c|c|c|c|}
\hline \multirow[t]{2}{*}{ Variabel } & \multirow{2}{*}{$\begin{array}{l}\text { Expected } \\
\text { Sign }\end{array}$} & \multicolumn{3}{|c|}{ Panel A } & \multicolumn{3}{|c|}{ Panel B } \\
\hline & & Tahun 1 & Tahun 2 & Tahun 3 & Tahun 1 & Tahun 2 & Tahun 3 \\
\hline $\mathrm{C}$ & & 0,85771 & 0,67983 & 0,66850 & 0,71054 & 0,50567 & 0,43106 \\
\hline GCG & + & $-0,09948$ & $-0,04319$ & 0,08500 & $-0,04768$ & 0,00195 & 0,16286 \\
\hline NPL & - & $-1,98237$ & $-0,82572$ & $-1,24828$ & $-2,05736$ & $-0,34150$ & $-1,04680$ \\
\hline CAR & + & $0,54433^{*}$ & $0,55266^{* * *}$ & $0,63647^{* * *}$ & $0,60782^{*}$ & $0,66518^{* * *}$ & $0,70550^{* * *}$ \\
\hline LOANTA & + & 0,09902 & $0,27507^{*}$ & $0,20854^{*}$ & 0,06344 & 0,13351 & 0,13914 \\
\hline SIZE & + & & & & 0,00854 & 0,01334 & $0,01408^{*}$ \\
\hline R-squared & & 0.18599 & 0,43881 & 0,47302 & 0,20538 & 0,47230 & 0,56759 \\
\hline Jumlah Ob & ervasi & 18 & 18 & 18 & 18 & 18 & 18 \\
\hline
\end{tabular}

Keterangan:

1. GCG mewakili variabel tata kelola, NPL mewakili variabel risiko kredit, CAR mewakili variabel kecukupan modal, LOANTA mewakili variabel intensitas pinjaman, dan SIZE merupakan variabel kontrol berupa total aset. Tingkat signifikansi $(\alpha)$ ditujukan dengan notasi $\left(^{* * *}\right)=1 \% ;\left(^{* *}\right)=5 \% ;\left(^{*}\right)=$ $10 \%$.

2. Angka pada setiap variabel dari setiap tahun merupakan besaran koefisien.

Sumber: Data hasil pengolahan

Variabel kecukupan modal mendukung hipotesis yang ada karena mampu konsisten memiliki hasil signifikan pada ketiga tahun setelah merger dan akuisisi. Variabel intensitas pinjaman dianggap mendukung hipotesis karena memiliki hasil signifikan pada tahun 2 dan tahun 3 setelah merger dan akuisisi.

Tata kelola yang diproksikan dengan komposisi jumlah komisaris independen terhadap jumlah direksi tidak memiliki pengaruh secara signifikan terhadap efisiensi bank setelah merger dan akuisisi. Hasil penelitian untuk tahun 1 dan tahun 2 sesuai dengan penelitian Widiarti, Siregar, \& Andati (2015) dan Permatasari \& Novitasary (2014) yang menyatakan bahwa tata kelola memiliki koefisien negatif namun tidak berpengaruh secara signifikan terhadap efisiensi (kinerja) bank. Hal tersebut terjadi karena adanya prinsip kehati-hatian dalam mengambil keputusan oleh manajemen (Permatasari \& Novitasary, 2014). Pada tahun 3 terdapat hasil koefisien positif, namun tidak terdapat pengaruh secara signifikan terhadap efisiensi bank setelah merger dan akuisisi. Hasil pada tahun 3 sesuai dengan penelitian Bokpin (2013) bahwa komposisi komisaris independen dalam jajaran petinggi perusahaan berpengaruh positif namun tidak signifikan terjadi bagi efisiensi bank.

Pada variabel risiko kredit, yang diproksikan dengan nonperforming loan ratio, tidak ditemukan pengaruh secara signifikan pada tahun 1, tahun 2, dan tahun 3 terhadap efisiensi bank setelah merger dan akuisisi. Sesuai dengan penelitian dari Sufian \& Majid (2007) yang menunjukkan bahwa masalah pinjaman (risiko kredit) tidak memiliki pengaruh secara signifikan terhadap efisiensi bank. Penelitian Mokhtar, Abdullah, \& Alhabshi (2007) menyatakan bahwa adanya bukti yang lemah (tidak signifikan) jika bank yang memiliki pinjaman bermasalah yang tinggi akan mempunyai tingkat efisiensi lebih rendah.

Kecukupan modal, diproksikan dengan capital adequcy ratio (CAR), memiliki pengaruh positif dan signifikan di tahun 1, tahun 2, dan tahun 3 terhadap efisiensi bank setelah merger dan akuisisi. Hasil penelitian ini sesuai dengan penelitian Sufian et al. (2016) yang menyatakan bahwa tingkat permodalan yang baik lebih memungkinkan menghadapi biaya yang lebih rendah bila terjadi kebangkrutan, kemudian dapat mengurangi biaya dalam meraih pendanaan. Sejalan dengan tujuan dilakukan merger dan akuisisi, yaitu salah satunya adalah untuk memenuhi jumlah modal minimal perbankan dalam rangka menciptakan sistem perbankan yang sehat dan struktur perbankan nasional yang kuat, sesuai dengan salah satu program yang dicanangkan Arsitektur Perbankan Nasional (API). Seluruh bank pada penelitian ini, dari tahun 1 sampai tahun 3 setelah merger dan akuisisi, mencapai 
tingkat CAR melebihi delapan persen sesuai yang tercantum pada Peraturan Bank Indonesia Nomor 10/15/PBI/2008 (2008).

Pada variabel intensitas pinjaman, yang menggunakan proksi loan to asset ratio, tidak memiliki pengaruh secara signifikan pada tahun 1 setelah merger dan akuisisi, tetapi memiliki pengaruh positif dan signifikan pada tahun 2 dan tahun 3 di panel A dan panel B, hasil panel (regresi) tertera pada Tabel 4. Hasil penelitian pada tahun 1, yang tidak signifikan, sesuai dengan penelitian Sufian et al. (2016) bahwa terdapat bukti yang lemah bahwa intensitas pinjaman dapat berpengaruh secara positif dan kuat terhadap efisiensi bank. Hasil tahun 2 dan tahun 3 sesuai dengan penelitian Isik \& Hassan (2003) bahwa loan to assets ratio (LOANTA) berdampak positif dan kuat pada efisiensi karena telah mencoba untuk mengkarakterisasi perusahaan yang efisien dengan melihat apakah ada hubungan antara efisiensi dan produksi pinjaman yang lebih besar. Rasio pinjaman terhadap aset yang lebih tinggi dapat mengimplikasikan kekuatan pasar yang lebih tinggi di pasar pinjaman. Kemampuan bank yang lebih produktif dalam mengelola operasional menyebabkan bank relatif mencapai biaya produksi yang lebih rendah, maka dari itu bank mampu menghasilkan pinjaman lebih banyak dan meningkatkan kekuatan pasar bank pada pasar pinjaman (loan market).

\section{SIMPULAN DAN SARAN}

Berdasarkan hasil analisis dan pembahasan pada penelitian di tahun 1, tahun 2, dan tahun 3 untuk menentukan faktor yang mempengaruhi efisiensi bank setelah merger dan akuisisi, menyatakan bahwa secara keseluruhan, hasil penelitian menunjukkan tata kelola tidak terdapat pengaruh signifikan terhadap setiap tahun efisiensi bank setelah merger dan akuisisi. Hasil penelitian menyatakan bahwa risiko kredit tidak berpengaruh signifikan terhadap efisiensi bank pada ketiga tahun setelah merger dan akuisisi. Hasil penelitian menunjukkan bahwa kecukupan modal berpengaruh positif dan signifikan terhadap efisiensi bank pada tahun 1, tahun 2, dan tahun 3 setelah merger dan akuisisi.

Melalui kecukupan modal yang baik, bank mampu melakukan mitigasi risiko dalam lingkup perusahaan maupun keadaan ekonomi makro sehingga mampu mencapai biaya yang lebih rendah dalam meraih pendanaan dan menyalurkan pinjaman. Hasil penelitian membuktikan bahwa intensitas pinjaman berpengaruh positif dan signifikan pada tahun 2 dan tahun 3 setelah merger dan akuisisi; namun tidak signifikan di tahun 1 . Produktivitas dalam menghasilkan pinjaman terbukti membentuk efisiensi bank setelah merger dan akuisisi, seiring perhatian terhadap kualitas pinjaman. Melalui simpulan yang telah diuraikan, maka saran yang dapat disampaikan dalam penelitian ini adalah menguji faktor lingkungan yang tercakup dalam Peraturan Bank Indonesia Nomor 13/1/PBI/2011 (2011) melalui metode RGEC (risk profile, good corporate governance, and earning capital) dengan menggunakan model Tobit.

\section{REFERENSI}

Badunenko, O., Fritsch, M., \& Stephan, A. (2006). What determines the technical efficiency of a firm? The importance of industry, location, and size (Issue December)

Bank Indonesia. (2011). Publikasi Laporan Keuangan Bank Umum Konvesional. https://www.bi.go.id/id/publikasi/laporan-keuangan/bank/umum-konvensional/Default.aspx. Diunduh tanggal 2 April 2018

Banker, R. D., Charnes, A., \& Cooper, W. W. (1984). Some models for estimating technical and scale inefficiencies in data envelopment analysis. Management Science, 30(9), 1078-1092. https://doi.org/10.1287/mnsc.30.9.1078

Berger, A. N., \& DeYoung, R. (1997). Problem loans and cost efficiency in commercial banks. Journal of Banking and Finance, 21(6), 849-870. https://doi.org/10.1016/S0378-4266(97)000034

Berger, A. N., \& Humphrey, D. B. (1997). Efficiency of financial institutions: International survey and directions for future research. European Journal of Operational Research, 98(2), 175-212. https://doi.org/10.1016/S0377-2217(96)00342-6

Bokpin, G. A. (2013). Ownership structure, corporate governance and bank efficiency: An empirical 
analysis of panel data from the banking industry in Ghana. The International Journal of Business in Society, 13(3), 274-287. https://doi.org/10.1108/CG-05-2010-0041

Charnes, A., Cooper, W. W., \& Rhodes, E. (1978). Measuring the efficiency of decision making units. European Journal of Operational Research, 2(6), 429-444. https://doi.org/10.1016/03772217(78)90138-8

Isik, I., \& Hassan, M. K. (2003). Efficiency, ownership and market structure, corporate control and governance in the turkish banking industry. Journal of Business Finance and Accounting, 30(910), 1363-1421. https://doi.org/10.1111/j.0306-686X.2003.05533.x

McGauran, M. (2017). The Indonesian banking industry: Unfolding the opportunity. In EY Parthenon (Issue March).

Mokhtar, H. S. A., Abdullah, N., \&Alhabshi, S. M. (2007). Technical and cost efficency of islamic banking in Malaysia. International Association for Islamic Economics, 11(October).

Mulyaningsih, T., \& Daly, A. (2012). Competitive conditions in banking industry: An empirical analysis of the consolidation, competition and concentration in the Indonesia banking industry between 2001 and 2009. Buletin Ekonomi Moneter dan Perbankan, 14(2), 151-186. https://doi.org/10.21098/bemp.v14i2.461

Niţoi, M., \& Spulbar, C. (2015). An examination of banks' cost efficiency in Central and Eastern Europe. Procedia Economics and Finance, 22, 544-551. https://doi.org/10.1016/S22125671(15)00256-7

Peraturan Bank Indonesia Nomor 8/14/PBI/2006 Tentang Perubahan Atas Peraturan Bank Indonesia Nomor 8/4/PBI/2006 Tentang Good Corporate Governance Bagi Bank Umum, (2006). https://www.bi.go.id/id/peraturan/perbankan/Pages/pbi_81406.aspx

Peraturan Bank Indonesia Nomor 8/16/PBI/2006 Tentang Kepemilikan Tunggal Pada Perbankan Indonesia, (2006). https://www.bi.go.id/id/peraturan/perbankan/Pages/pbi_81606.aspx

Peraturan Bank Indonesia Nomor 10/15/PBI/2008 Tentang Kewajiban Penyediaan Modal Minimum Bank Umum, (2008). https://www.bi.go.id/id/peraturan/perbankan/pages/pbi_101508.aspx

Peraturan Bank Indonesia Nomor 13/1/PBI/2011 Tentang Penilaian Tingkat Kesehatan Bank Umum, Peraturan Bank Indonesia 1 (2011). https://www.bi.go.id/id/peraturan/perbankan/Pages/pbi_130111.aspx

Peraturan Bank Indonesia Nomor 15/12/PBI/2013 Tentang Kewajiban Penyediaan Modal Minimum Bank Umum, (2013). https://www.bi.go.id/id/peraturan/perbankan/pages/pbi_151213.aspx

Permatasari, I., \& Novitasary, R. (2014). Pengaruh implementasi good corporate governance terhadap permodalan dan kinerja perbankan di Indonesia: Manajemen risiko sebagai variabel intervening. Jurnal Ekonomi Kuantitatif Terapan, 7(1), 52-59. https://doi.org/ISSN: 2301 - 8968

Rhoades, S. A. (1998). The efficiency effects of bank mergers: An overview of case studies of nine mergers. Journal of Banking \& Finance, 22(3), 273-291. https://doi.org/10.1016/S03784266(97)00053-8

Sufian, F., Kamarudin, F., \& Nassir, A. (2016). Determinants of efficiency in the Malaysian banking sector: Does bank origins matter? Intellectual Economics, 10(1), 38-54. https://doi.org/10.1016/j.intele.2016.04.002

Sufian, F., \& Majid, M. Z. A. (2007). Bank mergers performance and the determinants of Singaporean banks' efficiency: An application of two-stage banking models. Gadjah Mada International Journal of Business, 9(1), 19-39. http://i-lib.ugm.ac.id/jurnal/detail.php?dataId=11424

Sufian, F., Muhammad, J., Noordin, B. A. A., \& Kamarudin, F. (2013). Assessing the effect of mergers and acquisitions on revenue efficiency: Empirical evidence from the Malaysian banking sector. International Journal of Economic Research, 10(2), 297-313. https://doi.org/10.1177/097226291201600101

Sufian, F., \& Noor, M. A. N. M. (2009). The determinants of islamic banks' efficiency changes: Empirical evidence from the mena and asian countries islamic banking sectors. International Journal of Islamic and Middle Eastern Finance and Management, 2(2), 120-138. https://doi.org/10.1108/17538390910965149

Tanna, S., Pasiouras, F., \& Nnadi, M. (2011). The effect of board size and composition on the efficiency of UK banks. International Journal of the Economics of Business, 18(3), 441-462. https://doi.org/10.1080/13571516.2011.618617

Tri Santoso, R. (2010). Pengaruh merger dan akuisisi terhadap efisiensi perbankan di Indonesia (tahun 
Jurnal Manajemen Maranatha a Vol. 19 Nomor 2, Mei (2020)

1998-2009). Jurnal Akuntansi dan Keuangan, 12(2), 102-128.

http://puslit2.petra.ac.id/ejournal/index.php/aku/article/view/18187

Widiarti, A. W., Siregar, H., \& Andati, T. (2015). The determinants of banks' efficiency in Indonesia. Buletin Ekonomi Moneter dan Perbankan, 18(2), 129-156.

https://doi.org/10.21098/bemp.v18i2.520 